\title{
VI. On the crystalline form of some salts
}

\section{Mr. E.F. Teschemacher}

To cite this article: Mr. E.F. Teschemacher (1828) VI. On the crystalline form of some salts, Philosophical Magazine Series 2, 3:13, 27-29, DOI: 10.1080/14786442808674537

To link to this article: http://dx.doi.org/10.1080/14786442808674537

曲 Published online: 10 Jul 2009.

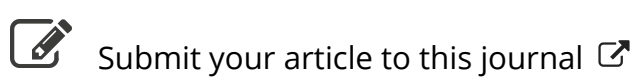

Џ Article views: 1

Q View related articles $₫$ 
was invisible; I never lost sight of it, till I saw both it and the smaller one quite clear of the moon.

But the larger one was so nearly occulted here, that it must have been quite so at a very small distance to the north-eastward; and it would be curious, and not quite useless as connected with the question of lunar parallax, if it should be found that the occultation was observed where the star's apparent path was an accurate tangent to the moon's limb.

I am, Gentlemen, yours, \&c.

Greenwich Hospital, Dec. 10, 1827.

E. RIDDLE.

VI. On the Crystalline Form of some Salts. By Mr. E. F. Teschemacher.

To the Editors of the Philosophical Magazine and Annals. Gentlemen,

BSERVING a paper in your Journal of December last, on some new double chromates, I beg to remark, that during an investigation which I made last winter, of some of the combinations of chromic acid with the different metals, I met with the same salts; and by an examination of their crystallographical character arrived at the same results as Mr. Henry Stokes, with regard to the combinations of sulphate of nickel and sulphate of zinc with chromate of potash, which, as they have not been before described, it may be interesting to detail.

Struck with the similarity in form of the crystals deposited by the solution containing nickel with some crystals of sulphate of nickel and potash given to me by Mr. H.J. Brooke, and described by him in the Annals of Philosophy, New Series, for December 1823; I subjected some very brilliant crystals of this new salt to an examination by Dr. Wollaston's reflective goniometer, which gave the following measurements. -Primitive form an oblique rhombic prism.

Chromo-sulphate of Nickel and Potash.

$\mathrm{P}$ on $\mathrm{M}$ or $\mathrm{M}^{\prime} 101^{\circ} 37^{\prime}$

$\mathrm{P}$ on $e \ldots 154 \quad 30$

$\mathrm{M}$ on $\mathrm{M}^{\prime} \ldots 107 \quad 37$

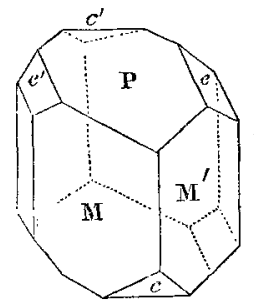

Sulphate of Nickel and Potash.

$\mathrm{P}$ on $\mathrm{M}$ or $\mathrm{M}^{\prime} 102^{\circ} 15^{\prime}$

P on $e$ or $e^{\prime} .154 \quad 32$

$\mathrm{M}$ on $\mathbf{M}^{\prime} \ldots 109 \quad 10$

A small difference in the meeting of the angles of these two salts E 2 


\section{$28 \mathrm{Mr}$. Teschemacher on the Crystalline Form of some Salts.}

will be observed. From this similarity of form I concluded this new salt to be a sulphate of nickel and potash combined with a small quantity of chromic acid, which is now further confirmed by comparing the analysis of the former salt made by Mr. Cooper, and inserted also in the same paper of $\mathrm{Mr}$. H.J. Brooke, with that of the new salt made by Mr. Stokes.

Sulphate of Nickel and Potash. Chromo-sulphate of Nickel and Potash.

Sulphuric acid . 18.95

Oxide of nickel . $8 \cdot 77$

Potash ... . 10.24

Water ..... 12.04

$50^{\circ}$
Sulphuric acid .. 18.260

Oxide of nickel . $8 \cdot 200$

Potash . . . . 9.862

Water ... . . 12:700

Chromic acid . . 0.978

Primitive form of both, an oblique rhombic prism.

Chromo-sulphate of Zinc and Potash.

Sulphate of Zinc and Potash.

$\mathrm{P}$ on $\mathrm{M} \ldots 101^{\circ} 47^{\prime}$

$\mathrm{P}$ on $\mathbf{M} \ldots 102^{\circ} 20^{\prime}$

$\mathrm{P}$ on $e \ldots .15431$

$\mathrm{M}$ on $\mathrm{M}^{\prime} \ldots \ldots 108 \quad 45$

$\mathbf{M}$ on $\mathbf{M}^{\prime} \quad \ldots 108 \quad 40$

This latter salt, the sulphate of zinc and potash, $I$ formed by adding pure potash to a solution of sulphate of zinc, separating the precipitate, and allowing the clear solution still containing oxide of zinc to crystallize. Not having made the analysis of this latter salt, I am unable to compare it with the analysis of the chromo-sulphate of potash and zinc as given by Mr. Stokes.

These are further instances in which the combination of minute quantities of matter vary the measure of the angles of crystals, and which show the value of Dr. Wollaston's goniometer in immediately detecting their existence.

I take this opportunity of sending you the measurements of the crystals of two other substances, which I am not aware have been previously given.

Hematin.

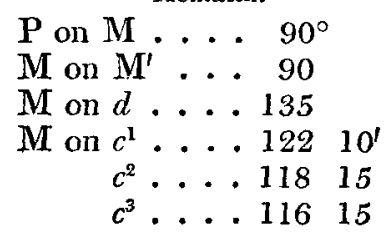

Primitive form a square prism.

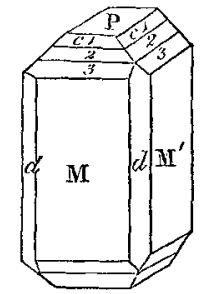

This substance was found in the interior of a piece of $\log$ wood ready formed in a crystalline mass; I merely dissolved 
the crystalline part in spirit of wine and obtained the hematin in regular crystals.

Tartrate of Strontian. Primitive form an oblique rhombic prism.

$$
\begin{aligned}
& \mathrm{P} \text { on } \mathrm{M} \\
& \mathrm{M} \text { on } \mathrm{M}^{\prime} \ldots 92^{\circ} 35^{\prime}
\end{aligned}
$$

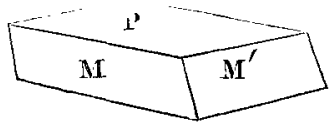

This salt was formed by adding a solution of tartrate of potash to one of nitrate of strontian.

On platina wire with borax before the blowpipe the chromosulphate of nickel and potash gives a transparent light brown glass; the chromo-sulphate of zinc and potash a transparent yellowish-green one.

Yours, \&c.

Barnsbury Park, Dec. 10, 1827.

E. F. Teschemacher.

VII. Remarks on Mr.J.Taylor's Rain-gauge. By B.Bevan, Esq.

To the Editors of the Philosophical Magazine and Annals. Gentlemen,

IN the last Number of your Magazine, at page 406, is a description of a rain-gauge by Mr. J. Taylor, in which a reference is made to my self-registering gauges, as described in a former Number*.

From the tenor of the paper, it may be supposed that the gauge invented by $\mathrm{Mr}$. Taylor was an improvement upon mine. Now setting aside as far as may be, a partiality for our own inventions, I am not able to see in what respect it can be denominated a registering instrument: it may serve, and doubtless will, to point ont the total quantity collected in the intervals of inspection, and so will the old simple floating index; but neither of them will show the time of commencement, the duration, and the rate of raining, for each shower,-which was effected by my gauges for some years: and although it was necessary to wind up the clock, and replace the paper on the cylinder once a week, it could not be considered any very objectionable trouble, considering the information it afforded; the whole operation might possibly occupy about five minutes, and as this occurred but once a week, it was not quite equal to the proportion of one minute per day.

I am aware, that to a gauge, such as is described by Mr. Taylor, additional apparatus might be applied, so as to render it a proper registering instrument; but at present it does not seem to possess any great superiority to the common floating gauges.

* See Philosophical Magazine and Annals, vol, ii. p. 74. 